\title{
WYBRANE ZAGADNIENIA INTERTEMPORALNE W ŚWIETLE ART. 9 ORAZ ART. 13 USTAWY Z DNIA 10 WRZEŚNIA 2015 R. O ZMIANIE NIEKTÓRYCH USTAW W ZWIAZZKU ZE WSPIERANIEM POLUBOWNYCH METOD ROZWIĄZYWANIA SPORÓW (DZ. U. 2015.1595)
}

\begin{abstract}
Selected intertemporal issues under the Art. 9 and 13 of the Act of 10 September 2015 on amendment of the Code of Civil Procedure

The aim of the present study is drawing attention to a problem of amendment of the Code of Civil Procedure. The author analyzes two problematic issues in the present legal state: changes in arbitrage and mediation and costs of mediation.
\end{abstract}

Słowa kluczowe: mediacja, arbitraż, Kodeks postępowania cywilnego, nowelizacja, koszty mediacji

Key words: mediation, arbitrage, Code of Civil Procedure, amendment, costs of mediation

W dniu 1 stycznia 2016 r. weszła w życie ustawa z dnia 10 września 2015 r. o zmianie niektórych ustaw w związku ze wspieraniem polubownych metod rozwiązywania sporów ${ }^{1}$. Ustawą tą do Kodeksu postępowania cywilnego (kpc) wprowadzono znaczące zmiany dotyczące postępowania mediacyjnego i arbitrażowego (art. 1 noweli). Zmianom wprowadzonym do kodeksu towarzyszy między innymi zmiana ustawy z dnia 28 lipca 2005 r. o kosztach sądowych w sprawach cywilnych ${ }^{2}$ (art. 7 noweli).

W niniejszym artykule uwaga zostanie ograniczona do zagadnień intertemporalnych wyłaniających się na tle nowych unormowań kpc oraz uksc odnoszących się do postępowania mediacyjnego.

1 Ustawa z dnia 10 września 2015 r. o zmianie niektórych ustaw w związku ze wspieraniem polubownych metod rozwiązywania sporów (Dz. U. 2015 r., poz. 1595 ze zm.), zwana dalej nowelą.

2 Ustawa z dnia 28 lipca 2005 r. o kosztach sądowych w sprawach cywilnych (tekst jedn. Dz. U. 2016 r., poz. 623), dalej uksc. 
Przepis art. 13 noweli stanowi, iż ustawa - w tym jej art. 1 (zmieniający kpc) oraz art. 7 (zmieniający uksc) wchodzą w życie w dniu 1 stycznia 2016 r. Jednocześnie przepis art. 9 noweli przewiduje, iż przepisy dotychczasowe stosuje się do postępowań wszczętych na podstawie ustawy zmienianej w art. 1 (to jest kpc) i niezakończonych przed dniem wejścia w życie niniejszej ustawy.

W praktyce orzeczniczej, na gruncie tej regulacji, funkcjonują dwie odmienne interpretacje dotyczące zastosowania dotychczasowych przepisów do postępowań mediacyjnych wszczętych od dnia 1 stycznia 2016 r., lecz na skutek skierowania sądu w związku z postępowaniem przed sądem wszczętym przed 1 stycznia $2016 \mathrm{r}$. Według jednego z poglądów za postępowania wszczęte na podstawie kpc przed dniem 1 stycznia 2016 r. - w rozumieniu art. 9 noweli - należy uznać postępowania sądowe wszczęte przed dniem 1 stycznia 2016 r., jak również postępowania mediacyjne wszczęte na skutek skierowania stron do mediacji w związku z tymi postępowaniami, nawet jeśli skierowanie stron nastąpiło po tej dacie. Według drugiego z poglądów za postępowania wszczęte, w rozumieniu ww. przepisu, należy uznać postępowania mediacyjne wszczęte przed dniem 1 stycznia 2016 r. Rozstrzygnięcie zarysowanego problemu rodzi istotne implikacje praktyczne, również w sprawach z zakresu prawa pracy ${ }^{3}$. Zdaniem autorki za prawidłowy należy uznać drugi z poglądów.

Zauważyć trzeba, iż omawianą nowelą do kpc w odniesieniu do postępowania mediacyjnego wprowadzono między innymi następujące zmiany:

1. upoważniono sąd do skierowania stron do mediacji na każdym etapie postępowania $\left(\text { art. } 183^{8} \$ 1 \mathrm{kpc}\right)^{4}$;

2. zniesiono ograniczenie, według którego sąd mógł skierować strony do mediacji wyłącznie raz w toku postępowania (por. brzmienie art. $183^{8} \$ 2 \mathrm{kpc}$ sprzed 1 stycznia 2016 r.);

3. dopuszczono skierowanie stron do mediacji również po skutecznym wniesieniu przez stronę sprzeciwu i zarzutów od nakazu zapłaty (art. $\left.183^{8} \$ 3 \mathrm{kpc}\right)^{5}$;

4. wprowadzono możliwość wezwania stron przed pierwszym posiedzeniem wyznaczonym na rozprawę do osobistego stawiennictwa na posiedzenie niejawne w celu oceny, czy skierować strony do mediacji, oraz wprowadzono instytucję spotkań informacyjnych dotyczących polubownych metod rozwiązywania sporów, w szczególności mediacji (art. $183^{8} \$ 4$ i 5 kpc);

3 W szczególności w zakresie zasad ponoszenia przez strony wynagrodzenia i wydatków mediatora, zasad rozliczania tych kosztów oraz możliwości obciążenia nimi Skarbu Państwa.

4 Dotychczas sąd mógł skierować strony do mediacji wyłącznie do zakończenia pierwszego posiedzenia wyznaczonego na rozprawę, późniejsze skierowanie było dopuszczalne wyłącznie na zgodny wniosek stron.

5 Dotychczas dominował pogląd, według którego wyłączone było skierowanie stron przez sąd do mediacji w postępowaniu upominawczym i nakazowym, również po wniesieniu sprzeciwu i zarzutów od nakazu zapłaty. 
5. wprowadzono możliwość obciążenia strony, która bez uzasadnienia nie stawi się na ww. posiedzeniu niejawnym lub spotkaniu informacyjnym, kosztami nakazanego stawiennictwa poniesionymi przez stronę przeciwną (art. $183^{8} \$ 6 \mathrm{kpc}$ );

6. wydłużono maksymalny termin sądowy, jaki sąd mógł w postanowieniu wyznaczyć stronom na mediację ${ }^{6}$, oraz przesądzono, iż czasu trwania mediacji nie wlicza się do czasu trwania postępowania;

7. zmieniono zasady, na jakich mediator może zapoznawać się z aktami sprawy $\left(\text { art. } 183^{9} \$ 2 \mathrm{kpc}\right)^{7}$;

8. wprowadzono nowy wymóg konstrukcyjny pozwu - podania informacji, czy strony podjęły próbę mediacji lub innego pozasądowego sposobu rozwiązania sporu, a w przypadku gdy takich prób nie podjęto, wyjaśnienie przyczyn ich niepodjęcia (art. $187 \$ 1$ pkt $3 \mathrm{kpc}$ );

9. rozszerzono obowiązki informacyjne sądu o pouczanie stron, również reprezentowanych przez profesjonalnych pełnomocników o możliwości ugodowego załatwienia sporu, w szczególności na drodze mediacji (art. $210 \$ 2^{2} \mathrm{kpc}$ );

10.w związku ze zmianą uksc w zakresie zasad rozliczania kosztów mediacji ze skierowania sądu rozszerzono katalog postanowień sądu I instancji zaskarżalnych zażaleniem o postanowienia, których przedmiotem jest wynagrodzenie mediatora (art. $394 \mathrm{w} \$ 1$ pkt $9 \mathrm{kpc}$ );

11. wprowadzono wyraźnie ustawowy obowiązek wyjawienia stronom niezwłocznie przez mediatora okoliczności, które mogłyby wzbudzić wątpliwości co do jego bezstronności (art. $183^{3} \$ 2 \mathrm{kpc}$ );

12. przesądzono wyraźnie dopuszczalność mediacji ewaluatywnej (art. $\left.183^{3 \mathrm{a}} \mathrm{kpc}\right)^{8}$;

13. rozciągnięto ustawowy obowiązek zachowania w poufności faktów ujawnionych w związku z prowadzeniem mediacji również na inne osoby biorące udział w mediacji (art. $\left.183^{4} \S 2 \mathrm{kpc}\right)^{9}$;

14. uzależniono obowiązek mediatora składania w sądzie protokołu z mediacji umownej, w której zawarto ugodę, od złożenia przez stronę wniosku o jej zatwierdzenie $\left(\text { art. } 183^{13} \S 1 \mathrm{kpc}\right)^{10}$;

6 Zamiast miesięcznego terminu dopuszczono wyznaczanie terminu do trzech miesięcy.

7 Dotychczas sąd mógł upoważnić mediatora do zapoznania się z aktami sprawy wyłącznie na zgodny wniosek stron, według noweli mediator ma prawo zapoznania się z aktami, chyba że strona w terminie tygodnia od ogłoszenia lub doręczenia postanowienia nie wyrazi zgody na zapoznanie się mediatora $\mathrm{z}$ aktami.

8 Na temat rozróżnienia mediacji facylitatywnej i ewaluatywnej zob. E. Gmurzyńska, Mediacja $w$ sprawach cywilnych $w$ amerykańskim systemie prawnym - zastosowanie w Europie i w Polsce, Warszawa 2007, s. 39 i n.

9 Dotychczas ustawowy obowiązek obejmował explicite jedynie mediatora i strony.

10 Dotychczas wymóg złożenia protokołu z mediacji umownej dotyczył każdej mediacji, w której zawarto ugodę niezależnie od tego, czy strony wnosiły o jej zatwierdzenie przez sąd. 
15.zmianie uległo znaczenie używanego przez kpc pojęcia stałego mediatora w związku ze zmianą przepisów ustrojowych - ustawy Prawo o ustroju sądów powszechnych ${ }^{11}$;

16. skutek przewidziany dla wszczęcia mediacji w postaci przerwy biegu terminu przedawnienia (art. $123 \$ 1$ pkt $3 \mathrm{kc}$ ), rozciągnięto na przypadki, o których mowa $\mathrm{w}$ art. $183^{6} \$ 2$ pkt $1-3 \mathrm{kpc}$, to jest sytuacje, w których do wszczęcia mediacji nie doszło z przyczyn niezależnych od strony występującej z inicjatywą mediacji, jeżeli strona wytoczy powództwo o roszczenie, które było objęte wnioskiem o przeprowadzenie mediacji w terminie trzech miesięcy od dnia, w którym mediator lub druga strona złożyli oświadczenie powodujące, że mediacja nie została wszczęta albo trzech miesięcy od dnia następnego po upływie tygodnia od dnia doręczenia wniosku o mediację, gdy mediator lub druga strona nie złożyli oświadczenia koniecznego do wszczęcia mediacji (art. $183^{6} \$ 3 \mathrm{kpc}$ ).

Jak już wspomniano, zmianom kodeksu towarzyszyła istotna zmiana w uksc w zakresie rozliczania kosztów mediacji ze skierowania sądu (art. 5 ust. 1 pkt 11 oraz art. 93 i 95 uksc) oraz w zakresie preferencyjnych zasad zwrotu całości lub części opłaty od pozwu w razie zawarcia ugody przed mediatorem (por. art. 79 uksc). Na skutek krytyki dotychczasowych rozwiązań, według których wynagrodzenie i wydatki mediatora nie stanowiły wydatków $\mathrm{w}$ rozumieniu $\mathrm{uksc}^{12}$, a w konsekwencji również strona zwolniona od kosztów sądowych była zmuszona ponosić koszty mediacji ze skierowania sądu ${ }^{13}$, do katalogu wydatków zaliczono koszty mediacji prowadzonej na skutek skierowania przez sąd ${ }^{14}$. Zgodnie $\mathrm{z}$ nowelizacją de lege lata koszty mediacji prowadzonej na skutek skierowania przez sąd za stronę zwolnioną od ponoszenia wydatków ponosi - tymczasowo, a niekiedy również ostatecznie - Skarb Państwa ${ }^{15}$.

Właściwa interpretacja przepisu intertemporalnego - art. 9 noweli - wymaga poczynienia spostrzeżeń o charakterze wstępnym. Po pierwsze, na podstawie art. 1 noweli zmieniono nie tylko przepisy proceduralne, lecz także przepisy o charakterze ustrojowym oraz o charakterze materialnoprawnym ${ }^{16}$. Po drugie, Kodeks postępowania

11 Ustawa z dnia 27 lipca 2001 r. Prawo o ustroju sądów powszechnych (t.j. Dz. U. 2015 r., poz. 133 ze zm.) - dalej pusp. Status stałego mediatora, na którego ustawodawca nakłada wyższe standardy, między innymi poprzez ograniczenie możności odmowy przeprowadzenia mediacji wyłącznie z ważnych powodów (art. $183^{2} \$ 4 \mathrm{kpc}$ ), został uzależniony od wpisu na listę stałych mediatorów na podstawie decyzji administracyjnej Prezesa Sądu Okręgowego, który przed wpisem weryfikuje kompetencje i doświadczenie kandydata (zob. art. 157a i n. pusp).

12 Zob. dawny art. 6 uksc.

13 Dotyczyło to między innymi pracownika korzystającego z tymczasowego, a częstokroć również ostatecznego zwolnienia od ponoszenia wydatków - zob. art. 96 ust. 1 pkt 4 oraz art. 97 uksc.

14 Nowelizacją dodano art. 5 ust. 1 pkt 11 i uchylono art. 6 uksc.

15 W szczególności w sprawach o roszczenia pracownika sąd może w orzeczeniu kończącym sprawę w instancji obciążyć pracownika tymi wydatkami, wyłącznie w szczególnie uzasadnionych przypadkach (art. 97 zd. 2 uksc).

16 Na potrzebę odróżnienia norm o charakterze ustrojowym od norm materialnoprawnych i procesowych zwraca się uwagę w nauce prawa administracyjnego. Zob. J. Zimmermann, Prawo administracyjne, 
cywilnego reguluje różne rodzaje postępowań ${ }^{17}$, dlatego wykładnia art. 9 noweli wymaga rozróżnienia postępowania sądowego, w którym następuje skierowanie stron do mediacji lub którego przedmiotem jest zatwierdzenie ugody zawartej przed mediatorem ${ }^{18}$ od samego postępowania mediacyjnego ${ }^{19} \mathrm{i}_{\text {mediacji }}{ }^{20}$.

Przepis intertemporalny art. 9 noweli mówi o stosowaniu przepisów dotychczasowych „do postępowań”. Oznacza to, że jego hipoteza odnosi się wyłącznie do przepisów proceduralnych, a nie ustrojowych czy materialnoprawnych. Odmienne stanowisko nie tylko byłoby sprzeczne z wykładnią gramatyczną, lecz także prowadziłoby do absurdalnych

Kraków 2005, s. 40-41. Na potrzebę wyróżnienia norm o charakterze ustrojowym, również na gruncie postępowania cywilnego, trafnie zwraca uwagę między innymi P. Osowy, Umowa o właściwość sądu jako przykład umowy przedprocesowej. Uwagi na tle art. 46 k.p.c., Kwartalnik Prawa Prywatnego 2005, 2, s. 668-671.

17 W literaturze przedmiotu wskazuje się, iż postępowanie cywilne nie ma charakteru jednolitego i obejmuje różne rodzaje postępowań. Tak między innymi W. Siedlecki, Z. Świeboda, Postępowanie cywilne. Zarys wykładu, Warszawa 2004, s. 24-30; W. Broniewicz, A. Marciniak., I. Kunicki, Postępowanie cywilne w zarysie, Warszawa 2016, s. 26-28. Na temat systemu postępowania cywilnego oraz zależności pomiędzy różnymi rodzajami postępowań zob. też S. Cieślak, Powiązania wewnątrzsystemowe w postępowaniu cywilnym, Warszawa 2013.

18 Na temat charakteru postępowania sądowego o zatwierdzenie ugody zawartej przed mediatorem, jego autonomiczności wobec postępowania, w którym doszło do skierowania stron do mediacji, oraz autonomiczności wobec postępowania sądowego zob. Ł. Błaszczak, Postępowanie sądowe w sprawach mediacyjnych, w: Mediacja w sprawach gospodarczych. Praktyka - teoria - perspektywy, A. Torbus (red.), Warszawa 2015, s. 273-280.

19 W literaturze przedmiotu wyróżnia się między innymi podział na postępowania sądowe (przed sądem państwowym) oraz postępowania pozasądowe toczące się przed innymi organami niż sądy państwowe (w tym postępowanie arbitrażowe, postępowanie przed komisjami pojednawczymi w sprawach o roszczenia pracowników z zakresu prawa pracy). Rozróżnienia takiego dokonali W. Siedlecki, Z. Świeboda, Postępowanie cywilne..., s. 24-30. Według tego podziału postępowanie mediacyjne należy zaliczyć do postępowań pozasądowych. Tak również: K. Weitz, K. Gajda-Roszczynialska, Alternatywne metody rozwiqzywania sporów ze szczególnym uwzględnieniem mediacji, w: Mediacja w sprawach gospodarczych. Praktyka - teoria - perspektywy, A. Torbus (red.), Warszawa 2015, s. 57; Ł. Błaszczak, w: Postępowanie cywilne, E. Marszałkowska-Krześ (red.), Warszawa 2011, s. 532. Nieco odmiennie W. Broniewicz, A. Marciniak., I. Kunicki, Postępowanie cywilne..., s. 26, który postępowanie mediacyjne wymienia w ramach postępowania procesowego. Zob. też S. Cieślak, Powiązania wewnątrzsystemowe..., s.126 i 168, który zauważa, że „postępowanie mediacyjne ma charakter w pełni alternatywnyw stosunku do innych postępowań procesowych i w związku z tym obydwa zbiegające się postępowania mogą przebiegać równolegle. Mamy w tym wypadku do czynienia z zasadą kumulacji tych postępowań w postaci ich równoległego przebiegu".

20 W literaturze przedmiotu wyrażono pogląd o potrzebie rozróżnienia pojęcia mediacji (rozumianej jako „wzajemne procedowanie mediatora ze stronami, zmierzające do zawarcia ugody, polegające w szczególności na składaniu przez strony propozycji ugodowych, propozycji wzajemnych ustępstw lub innych oświadczeń, podczas posiedzeń mediacyjnych, bądź w inny sposób, w przypadku gdy posiedzenia mediacyjne nie są organizowane”) od pojęcia postępowania mediacyjnego (rozumianego jako „czynności podejmowane przez strony lub uczestników postępowania cywilnego oraz mediatora, związanych z rozpoczęciem, przebiegiem i zakończeniem mediacji”). Zob. K. Markiewicz, Postępowanie mediacyjne, w: Mediacja w sprawach gospodarczych. Praktyka - teoria - perspektywy, A. Torbus (red.), Warszawa 2015, s. 248, który aprobuje pogląd G. Frączka, wyrażony w niepublikowanej rozprawie doktorskiej pt. Wszczęcie postępowania mediacyjnego, Katowice 2015, s. 17-18. 
rezultatów. Należy podkreślić, iż o zaliczeniu przepisów do danej kategorii nie decyduje samo umiejscowienie przepisu w ustawie procesowej lub materialnoprawnej.

Przepisami o charakterze ustrojowym będą niewątpliwie wprowadzone nowelą unormowania pusp dotyczące statusu stałych mediatorów. Z dniem 1 stycznia $2016 \mathrm{r}$. dotychczasowi stali mediatorzy stali się mediatorami, a status stałych mediatorów, z którym kpc wiąże szczególne konsekwencje (zob. art. $183^{2} \$ 4,183^{6} \$ 2$ pkt 1 kpc), został zastrzeżony wyłącznie dla mediatorów wpisanych na listę stałych mediatorów na podstawie decyzji prezesa sądu okręgowego. Oznacza to, iż począwszy od dnia 1 stycznia 2016 r. wprowadzone do pusp pojęcie stałego mediatora, używane między innymi w art. $183^{2} \$ 4$ i art.183 $\$ 2$ pkt 1 kpc, należy rozumieć w sposób nadany mu nowelą, niezależnie od tego, czy czynności mediatora dokonywane są w postępowaniu wszczętym przed tą datą.

Za przepis o charakterze materialnoprawnym należy uznać dodany nowelą art. $183^{6}$ $\$ 3 \mathrm{kpc}$. Przepis ten, pomimo położenia w ustawie procesowej, poszerza zawarty $\mathrm{w}$ art. $123 \$ 1$ kc katalog zdarzeń skutkujących przerwą biegu terminu przedawnienia ${ }^{21}$. Materialnoprawny charakter przepisu nakazuje przyjąć, iż skutek w postaci przerwy biegu terminu przedawnienia na podstawie art. $183^{6} \$ 3$ kpc będzie dotyczył przypadków, w których zdarzenie, $\mathrm{z}$ którym ustawa wiąże skutek w postaci przerwy biegu terminu przedawnienia, to jest doręczenie mediatorowi wniosku o wszczęcie mediacji z załączonym dowodem doręczenia jego odpisu drugiej stronie (art. $183^{6} \$ 1 \mathrm{kpc}$ ), nastąpiło, począwszy od dnia 1 stycznia $2016 \mathrm{r}^{22}$

Pozostałe wymienione wyżej w pkt. 1-14 zmiany kodeksu dotyczą przepisów proceduralnych. Nie jest to jednak jednolity katalog. Część tych unormowań odnosi się bowiem do postępowania sądowego związanego z kierowaniem stron do mediacji (unormowania wymienione w pkt. 1-10), a część z tych unormowań odnosi się do postępowania mediacyjnego (unormowania wymienione w pkt. 11-14). Podkreślenia wymaga fakt, iż postępowanie mediacyjne niezależnie od tego, czy chodzi o tak zwaną mediację

21 Zob. P. Telenga, w: Komentarz aktualizowany do ustawy z dnia 17 listopada 1964 r. Kodeks postępowania cywilnego, A. Jakubecki (red.), Lex 2016, Komentarz aktualizowany do art. 183(6). Autor wyraża pogląd, iż w sprawach ze stosunku pracy wszczęcie mediacji nie wywołuje skutku w postaci przerwy biegu terminu przedawnienia. Wniosek taki wywodzi z art. $295 \mathrm{w}$ zw. z art. $300 \mathrm{kp}$ a contrario. Wydaje się jednak, iż wniosek ten jest zbyt daleko idący. Należy przyjąć, iż wszczęcie mediacji przerywa bieg terminu przedawnienia również w odniesieniu do roszczeń ze stosunku pracy. Podobnie A. Kosut, w: Kodeks pracy. Komentarz, red. K.W. Baran (red.), Lex 2016, Komentarz do art. 295 kp, teza 1; K. Jaśkowski, w: Komentarz aktualizowany do ustawy z dnia 26 czerwca 1974 r. Kodeks pracy (Dz. U. 98.21.94), K. Jaśkowski, M. Maniewska (red.), Lex 2017, Komentarz do art. 295 kp, teza 3.

22 Zob. Art. XXXV ustawy z dnia 23 kwietnia 1964 r. przepisy wprowadzające kodeks cywilny (Dz. U. 1964 r., Nr 16, poz. 94 ze zm.) oraz wyrok SN z 25 maja 2007 r. (I CSK 84/07, OSNC-ZD 2008/2/35), w którym SN wskazał, że przepisy międzyczasowe zawarte w ustawie z dnia 23 kwietnia 1964 r. - Przepisy wprowadzające Kodeks cywilny (Dz. U., Nr 16, poz. 94 ze zm.) mają zastosowanie na drodze analogii do ustaw nowelizujących Kodeks cywilny, chyba że stanowią one inaczej. 
instytucjonalną (ze skierowania sądu), czy o mediację umowną ${ }^{23}$, jest postępowaniem pozasądowym i autonomicznym wobec postępowania sądowego ${ }^{24}$.

W świetle powyższego postępowania mediacyjnego, również wszczętego na skutek skierowania przez sąd, nie można utożsamiać z postępowaniem sądowym, w którym nastąpiło skierowanie. Z tego względu należy przyjąć, iż w postępowaniach mediacyjnych wszczętych od dnia 1 stycznia 2016 r., w tym postępowaniach mediacyjnych wszczętych na skutek postanowienia o skierowaniu stron do mediacji wydanego w postępowaniu sądowym wszczętym przed dniem 1 stycznia 2016 r., zastosowanie znajdą przepisy regulujące postępowanie mediacyjne w brzmieniu nadanym im nowelą. Z kolei w postępowaniach sądowych wszczętych przed dniem 1 stycznia 2016 r. znajdą zastosowanie dotychczasowe przepisy kpc zawarte w oddziale zatytułowanym „Mediacja”, lecz odnoszące się do postępowania sądowego.

Właściwe zastosowanie art. 9 noweli wymaga precyzyjnego określenia momentu wszczęcia postępowania mediacyjnego. W przypadku tak zwanej mediacji umownej momentem wszczęcia postępowania mediacyjnego w rozumieniu art. 9 noweli będzie zgodnie z art. 183 (6) $\$ 1$ kpc chwila doręczenia mediatorowi wniosku o przeprowadzenie mediacji z dowodem doręczenia jego odpisu drugiej stronie ${ }^{25}$. W przypadku tak zwanej mediacji instytucjonalnej (ze skierowania sądu) za moment wszczęcia postępowania mediacyjnego (ale jeszcze nie wszczęcia mediacji) - w rozumieniu art. 9 noweli - należy uznać moment wydania przez sąd postanowienia o skierowaniu stron do mediacji ${ }^{26}$. Tak określony moment wszczęcia postępowania mediacyjnego ${ }^{27}$ powinien być rozstrzygający dla zastosowania znowelizowanych przepisów regulujących postępowanie mediacyjne.

Powyższe uwagi prowadzą również do wniosku, iż skoro wynagrodzenie i wydatki mediatora od dnia 1 stycznia 2016 r. zostały zaliczone do wydatków w rozumieniu uksc ${ }^{28}$, to niezależnie od daty wszczęcia postępowania sądowego powinny być one rozliczane

${ }^{23} \mathrm{Na}$ temat rodzajów mediacji zob. z wielu K. Weitz, K. Gajda-Roszczynialska, Alternatywne..., s. 55 i powołana tam literatura.

${ }^{24}$ Zob. przypis 17.

${ }_{25}$ Podobnie o momencie wszczęcia mediacji M. Białecki, Mediacja w postępowaniu cywilnym, Warszawa 2012, s. 176; K. Markiewicz, Postępowanie mediacyjne..., s. 249 i 260.

${ }^{26} \mathrm{~W}$ piśmiennictwie brak jest precyzji i jednomyślności co do określenia momentu wszczęcia postępowania mediacyjnego w przypadku mediacji instytucjonalnej. Por. R. Morek, w: Mediacje. Teoria i praktyka, E. Gmurzyńska, R. Morek (red.), Warszawa 2014, s. 294; M. Białecki, Mediacja..., s. 180; A. Arkuszewska, A. Kościółek, w: Zarys metodyki pracy mediatora w sprawach cywilnych, A.M. Arkuszewska, J. Plis (red.), Warszawa 2014, s. 105-107. W przypadku mediacji instytucjonalnej szczególnego znaczenia nabiera odróżnienie wszczęcia postępowania mediacyjnego od wszczęcia mediacji. Mimo wszczęcia postępowania mediacyjnego na podstawie skierowania do mediacji nie dojdzie, jeżeli strony nie wyrażą na nią zgody. Podobnie K. Markiewicz, Postępowanie mediacyjne..., s. 264.

${ }^{27} \mathrm{Na}$ marginesie wskazać również należy, iż w literaturze przedmiotu podkreśla się, iż ustawodawca rozróżnia pojęcia mediacji i postępowania mediacyjnego, oraz podnosi się, że moment wszczęcia postępowania mediacyjnego nie jest tożsamy z momentem wszczęcia mediacji.

${ }^{28}$ Należy przyjąć, iż przepis art. 5 ust. 1 pkt 11 uksc zaliczający koszty mediacji instytucjonalnej do wydatków nie jest w istocie przepisem proceduralnym. 
zgodnie z art. 130 (4) kpc oraz art. 83 uksc, przyznane zaś stronie, czy to przez ustawę, czy to przez sąd, zwolnienie od ponoszenia wydatków rozciąga się na wynagrodzenie i wydatki mediatora związane z mediacją instytucjonalną. W szczególności w sprawach o roszczenia pracownika, $\mathrm{w}$ tym również $\mathrm{w}$ razie skierowania do mediacji dokonanego w postępowaniu sądowym wszczętym przed 1 stycznia 2016 r., pracownik jest tymczasowo zwolniony od ponoszenia wynagrodzenia i wydatków mediatora, a obciążenie go tymi kosztami na podstawie art. 113 uksc w postępowaniu kończącym postępowanie w instancji może nastąpić wyłącznie w szczególnie uzasadnionych przypadkach (art. $97 \mathrm{zd} .2$ uksc).

Nie można nie dostrzegać pewnych problemów, jakie wyłaniają się w związku z proponowaną interpretacją art. 9 noweli. W szczególności należy wskazać, iż niewątpliwie przepisem o charakterze proceduralnym, odnoszącym się do postępowania sądowego, jest art. $394 \$ 1$ pkt $9 \mathrm{kpc}$. Jego nowe brzmienie znajdzie zastosowanie wyłącznie w ramach postępowań sądowych wszczętych od dnia 1 stycznia 2016 r. Omawianą nowelą do zawartego w nim katalogu postanowień sądu I instancji zaskarżalnych zażaleniem dodano postanowienia, których przedmiotem jest wynagrodzenie mediatora. Oznacza to istnienie luki w zakresie dopuszczalności zaskarżania tej kategorii postanowień wydanych od 1 stycznia 2016 r., ale w ramach postępowań sądowych wszczętych przed tym dniem. Lukę tę należy uzupełnić na drodze analogii z art. $394 \$ 1$ pkt $9 \mathrm{kpc}$ w zakresie, w jakim w brzmieniu sprzed 1 stycznia 2016 r. przewidywał on zaskarżanie postanowień w przedmiocie wynagrodzenia biegłego czy też należnych pełnomocnikowi z urzędu kosztów nieopłaconej pomocy prawnej ${ }^{29}$.

Podsumowując, pomimo pozornie jasnego brzmienia przepisy intertemporalne art. 9 i 13 ustawy z dnia 10 września 2015 r. o zmianie niektórych ustaw w związku ze wspieraniem polubownych metod rozwiązywania sporów wymagają wykładni. Prawidłowa wykładnia tych przepisów jest możliwa wyłącznie przy uwzględnieniu charakteru poszczególnych zmienianych unormowań (a to zakwalifikowania ich do regulacji procesowych, materialnoprawnych i ustrojowych) oraz przy uwzględnieniu pozasądowego charakteru i autonomiczności postępowania mediacyjnego w stosunku do postępowania sądowego, w którym może dojść do skierowania stron do mediacji. Wykładnia tych przepisów ma szczególne praktyczne znaczenie dla odpowiedzi na pytanie, czy zwolnienie od wydatków (w rozumieniu uksc) obejmuje wynagrodzenie i wydatki mediatora związane z postępowaniem mediacyjnym wszczętym na podstawie postanowienia sądu wydanego od dnia 1 stycznia 2016 r. w postępowaniu sądowym wszczętym przed tym dniem. Na powyższe pytanie należy udzielić odpowiedzi twierdzącej. Z tego względu nie sposób zaaprobować funkcjonującej w praktyce orzeczniczej

29 Na marginesie należy wskazać, iż ustawodawca, zmieniając zasady rozliczania wydatków związanych z mediacją instytucjonalną, nie przewidział explicite dopuszczalności zaskarżania postanowień sądu II instancji w przedmiocie wynagrodzenia mediatora. Wprowadzając te postanowienia do katalogu z art. $394 \$ 1$ pkt 9, nie rozszerzył katalogu przewidzianego w art. $394(2) \$ 1$ kpc. Również ta luka powinna zostać uzupełniona na drodze analogii do zaskarżania postanowień sądu II instancji w przedmiocie zwrotu kosztów nieopłaconej pomocy prawnej udzielonej z urzędu. 
wykładni, jakoby o zastosowaniu nowych lub dotychczasowych przepisów regulujących postępowanie mediacyjne oraz zasady rozliczania kosztów mediacji instytucjonalnej miała decydować wyłącznie data wszczęcia postępowania sądowego.

\section{Bibliografia}

Arkuszewska A., Kościółek A., w: Zarys metodyki pracy mediatora w sprawach cywilnych, A.M. Arkuszewska, J. Plis (red.), Warszawa 2014.

Białecki M., Mediacja w postępowaniu cywilnym, Warszawa 2012.

Błaszczak Ł., Postepowanie sadowe w sprawach mediacyjnych, w: Mediacja w sprawach gospodarczych. Praktyka - teoria - perspektywy, A. Torbus (red.), Warszawa 2015.

Błaszczak Ł., w: Postępowanie cywilne, E. Marszałkowska-Krześ (red.), Warszawa 2011.

Broniewicz W., Marciniak A., Kunicki I., Postępowanie cywilne w zarysie, Warszawa 2016.

Cieślak S., Powiązania wewnątrzsystemowe w postępowaniu cywilnym, Warszawa 2013.

Gmurzyńska E., Mediacja w sprawach cywilnych $w$ amerykańskim systemie prawnym - zastosowanie w Europie $i$ w Polsce, Warszawa 2007.

Jaśkowski K., w: Komentarz aktualizowany do ustawy z dnia 26 czerwca 1974 r. Kodeks pracy (Dz. U. 98.21.94), K. Jaśkowski, M. Maniewska (red.), Lex 2017.

Kosut A., w: Kodeks pracy. Komentarz, red. K.W. Baran (red.), Lex 2016.

Markiewicz K., Postępowanie mediacyjne, w: Mediacja w sprawach gospodarczych. Praktykateoria - perspektywy, A. Torbus (red.), Warszawa 2015.

Morek R., w: Mediacje. Teoria i praktyka, E. Gmurzyńska, R. Morek (red.), Warszawa 2014.

Osowy P., Umowa o właściwość sądu jako przykład umowy przedprocesowej. Uwagi na tle art. 46 k.p.c., Kwartalnik Prawa Prywatnego 2005, 2.

Siedlecki W., Świeboda Z., Postępowanie cywilne. Zarys wykładu, Warszawa 2004.

Telenga P., w: Komentarz aktualizowany do ustawy z dnia 17 listopada 1964 r. Kodeks postępowania cywilnego, A. Jakubecki (red.), Lex 2016.

Weitz K., Gajda-Roszczynialska K., Alternatywne metody rozwiązywania sporów ze szczególnym uwzględnieniem mediacji, w: Mediacja w sprawach gospodarczych. Praktyka - teoria - perspektywy, A. Torbus (red.), Warszawa 2015.

Zimmermann J., Prawo administracyjne, Kraków 2005. 